Temple, Sir F. Treves, Sir Thomas Barlow and other distinguished physicians, Sir Edward Fry, and Sir Harry Johnston, by Dr. A. E. Shipley and Dr. Gregory Foster, by Mrs. Creighton and Mrs. J. R. Green, by Messrs. Halsey Ricardo, Walter Sichel, and Frank Brangwyn, as well as by a number of distinguished people more immediately connected with museums of art or science. The dubious economy of the proposal was well brought out in letters by $\mathrm{Mr}$. G. W. Prothero and a "Past President of the Museums Association."

In a few cases the writers attempted to overcome difficulties which really do not exist. The claim that the closing alone will effect a saving of 5o,oool. cannot be maintained in the light of Lord Morley's figure of only a little more than $2000 l$. for the huge Natural History Museum. The idea that the galleries of this museum could be used for clerical work was, we believe, suggested some time ago, but presumably found impracticable. Many suspect a reason in the greater safety of the collections; but this was attended to long since, and the removal of the more valuable objects from the public galleries of various museums has not impaired their educational activities; indeed, the contrary has been maintained. The idea that a number of active young men are still at work in these establishments is on a par with the myth of the policemen of military age. No body of men rushed more readily to the colours, and we do not believe that one is left to be compelled. If convalescent soldiers were employed to watch the galleries they would only release veterans who are, or soon will be, candidates for Chelsea Hospital; far better let the commissionaires, who perform their duties so admirably, stay where they are, and employ the convalescents elsewhere. One offer, however, might well be accepted: if there are competent people willing to help with demonstrations in the galleries, by all means let them. Even if red tape delays an official welcome, there is nothing to prevent them from organising small parties on their own initiative, and so doing a really useful work. Such aid would at all times be valuable on Sunday afternoons.

The Government may withdraw, but have our rulers learned their lesson? Do they understand that, instead of suppressing museums, they should utilise them? And the museum-people in their turn-possibly if some of them were a little more ready to adapt their exhibitions to the necessities of the time, no Government would dream of dispensing with such potent allies.

\section{SIR CLEMENTS ROBERT MARKHAM, K.C.B., F.R.S.}

I UST the accident of setting his bed alight with a candle, and the shock resulting from his effort to subdue the flames, led to the death of Sir Clements Markham on the evening of Sunday last, January 30, at his residence in Eccleston Square, London.

NO. 24 I 4 , VOL. 96$]$
Sir Clements was in his eighty-sixth year, and although intellectually vigorous he had been a sufferer from gout for some years past, and was frequently confined to his room, where his active mind was ever engaged in those literary researches in the field of geography the results of which are so well and so widely known. He was a member of a good old northern family; his great-grandfather (not his grandfather as stated in the Times) was Archbishop of York, and at one time Headmaster of Westminster School, a fact which accounts for the deep interest in that school which was maintained by Sir Clements during his lifetime. His grandfather was William Markham, private secretary to Warren Hastings and resident at Benares, who stood in the same relationship to Admiral Sir Albert Hastings Markham as to Sir Clements.

Sir Clements Markham was born at Stillingfleet in Yorkshire, his father (Rev. David Markham) being vicar of that parish and Canon of Windsor. His mother was a Milner. The Markhams were a naval family, and young Clements followed the family profession, entering the Service in 1844 and retiring as a lieutenant in $185^{2}$. $\mathrm{His}$ early experiences as a sailor coloured his scientific outlook during his whole career. He was a devoted friend to the sailor, and this devotion led to an enthusiastic support of naval (Royal Naval) enterprise in Arctic and Antarctic fields which occasionally pressed rather hard on the requirements of other geographical projects. It was as a sailor, after his experiences with the Franklin Search Expedition in $185^{0}-51$, that he commenced his literary career, a career which marked him as perhaps the most prolific geographical writer of the day.

So early as $185^{2}$ Sir Clements acquired his first experiences as a land explorer in South America, when he visited Peru on a quest for information about the Inca period, and it was there that he made those investigations which rendered him an expert authority on that country. His greatest work in the cause of humanity was undoubtedly the introduction of cinchona from Peru into India, on which enterprise he was employed by the Secretary of State for India in $1859-60$. He was successful both in the collection of plants and in the arrangement of plantations in India. The beneficial results of that enterprise to the fever-stricken plains and jungles of India can only be compared with those which have been attained by the discovery of the germ-carrying mosquito. Quinine was at once placed within financial reach of the mass of the people. Peruvian experiences formed the subject of books and pamphlets which appeared from his pen at intervals for many years. "The Incas of Peru," published in I9ro, was the latest.

From 1863 to 1888 Sir Clements was one of the Hon. Secretaries of the Royal Geographical Society. They were busy years when pioneer explorations from every part of the known world into regions of the unknown were leading to sensational revelations and extending our geographical map knowledge with great rapidity. His position as 
secretary brought him into direct contact with most of the leading explorers of the day, and his untiring energy and literary ability were of the greatest service to the Society in collating and recording the result of world-wide investigations. $\mathrm{He}$ received the gold medal of the Society in 1888 , when he became its president, a position which he held for eight years. Meanwhile, in 1868, he joined the expedition which reached Magdala (Abyssinia) under Lord Napier; and it is evidence of his unusual capacity both for personal observation and the collection of material which would in these days be classed under the head of "intelligence," that he wrote the best popular account of that remarkable expedition which has yet appeared. For ten years after this Sir Clements was in charge of the Geographical Department of the India Office, and this appointment gave him the opportunity for rescuing from oblivion the neglected records of the Indian Navy, and of writing a history of the Indian Survey. The latter is the only popular work on this subject which exists, and it much wants a writer of the ability of Sir Clements to bring it up to date.

As president of the Royal Geographical Society Sir Clements Markham has left an abiding name. It is not too much to say that he gave his whole soul to the work of maintaining the usefulness of the Society in every branch of geographical activity. He succeeded in impressing the administrative authorities of Government, as well as those of the leading universities, with the necessity for widespread geographical education. Geographical schools and teachers began to be busy, and much of the present interest which is maintained in maps (to be found in every newspaper now) is due to his initiative. If Sir Clements appeared to be somewhat autocratic in council it is at least due to him to say that it was his personal determination which carried through many a project which would have failed in weaker hands. Notably he must be credited with the success of the first Antarctic expedition under his own nominee, Captain Scott. That expedition gave an impetus to Antarctic discovery which has not ceased yet. As president at the meetings of the Society he was a clear and vigorous speaker, and he always succeeded in importing something of his own vitality into every subject which he handled. A firm, strong friend was Sir Clements, and a somewhat pugnacious enemy; a man of strong views, and possessed of that rare courage-the courage of his opinions. As president of the Hakluyt Society he rescued many an old record from oblivion, and has given to the world a series of most interesting books of ancient adventure and travel-works which will survive through the ages.

T. H. HoLdich.

\section{NOTES.}

THE issue of Science for December 24 last prints an address by Dr. L. H. Baekeland delivered before a recent joint meeting of the New York Section of the American Chemical Society, the American Electrochemical Society, and the Society of Chemical Industry, on the recent proposals of the Naval Consulting
Board of the United States. Dr. Baekeland is a member of the board, and this address is the first public report of the discussions of the board on the so-called "five-million laboratory" proposed by the Naval Consulting Board. The contemplated outlay for the navy for the next five years, for new ships, aviation, and reserve of munitions, amounts to $100,000,000 l$, and the argument of the address is that an expenditure of this magnitude ought to be made as efficient as possible. All doubtful and inferior devices must be eliminated by direct experiment, by research and tests, before it is too late to remedy them. The advisory board has stated the facts as it saw them, and confronted the secretary of the navy with the probable maximum expenses for research and experimentation, commensurate to the five years' naval building programme now under contemplation. The five-million dollar budget, or $1,000,000 l$, for experimental work to be expended during those five years, or about $200,000 l$. a year, may, says Dr. Baekeland, strike the uninitiated as needlessly large, although it is only about what some industrial enterprises have found necessary to spend on their own experimental work. The corrosion of condenser tubes of American warships involves an annual damage of about $400,000 \mathrm{l}$. If $200,000 \mathrm{l}$. were spent on research on this problem alone, with the result of reducing the damage to one-half, the total outlay would be compensated in a few months' time, aside from the important fact that the fleet would be stronger because less of the ships would be unavailable for service.

Dr. C. Gordon Hewitt, dominion entomologist of Canada, has been elected president of the American Association of Economic Entomologists for 1916.

AT the annual meeting of the Challenger Society on January 26 the following officers were elected for the ensuing year:-Secretary, Mr. C. Tate Regan; Treasurer, Mr. E. T. Browne; Committee, Dr. S. F. Harmer, Mr. D. G. Lillie, and Prof. E. W. McBride.

THE gold medal of the Royal Astronomical Society has been awarded to Dr. J. L. E. Dreyer, for his contributions to astronomical history and his catalogues of nebulæ; and it will be presented at the annual meeting of the society to be held on Friday, February II.

THE annual meetings of the Institution of Naval Architects will be held on Wednesday, April 12, and the following day, in the hall of the Royal Society of Arts, John Street, Adelphi, W.C. Owing to the continuance of the war, the council has decided that it would be unsuitable for the customary entertainments to be given; the annual dinner and evening reception will accordingly not take place.

THE death is announced of Mr. F. M. Webster, a leading American entomologist, at the age of sixty-six. $\mathrm{He}$ was professor of entomology at Purdue University from 1885 to 1888 , and had held various scientific official positions in connection with the States of Illinois, Indiana, and Ohio, as well as the Federal Department of Agriculture. At the time of his death he was in charge of the cereal and forage-crop insect 